\title{
Existem direitos de solidariedade? A tradição clássica e as propostas liberais ${ }^{*}$
}

\author{
Are there Rights of Solidarity? The Classical Tradition and the Liberal Proposals
}

\author{
Carlos Ignacio Massini-Correas $^{* *}$
}

\begin{abstract}
REFERÊNCIA
MASSINI-CORREAS, Carlos I. Existem direitos de solidariedade? A tradição clássica e as propostas liberais. Revista da Faculdade de Direito da UFRGS, Porto Alegre, n. 42, p. 45-62, abr. 2020. DOI: $<\mathrm{https}$ ://doi.org/10.22456/0104-6594.102156>.
\end{abstract}

\begin{abstract}
RESUMO
No presente trabalho, o autor começa explicando os vários significados do termo "solidariedade", em especial no que se refere a fato social ou a uma atitude ou ação ética, fazendo referência somente ao aspecto ético da solidariedade. Após, estuda-se o fundamento da solidariedade ética, que se encontra na noção de bem comum, concebendo-se como uma perfeição em que participam aqueles que integram um todo relacional-prático. Logo se analisa o modo com que o pensamento liberal primeiramente debilitou e depois eliminou a noção de bem comum, centrando-se em bens meramente individuais e impossibilitando a justificação racional da solidariedade ética, seja concretando em direitos, virtudes, normas, deveres ou nas realidades remanescentes dessa índole. Nas conclusões, reivindica-se a vinculação necessária entre a solidariedade ética e a ideia de bem comum.
\end{abstract}

\section{PALAVRAS-CHAVE}

Solidariedade. Ética. Bem comum. Liberalismo.

\begin{abstract}
The author begins by explaining the various meanings of the concept "solidarity", especially those referring to a certain social fact or an ethical attitude or activity, taking the ethic expression of the solidarity. Then we proceed to study the foundation of ethical solidarity, if it is found in the notion of the common good, if it is conceived as a perfection of the participants that integrate a relational-practical whole. Then we analyzed the way in which liberal thought first has been weakened and then eliminated the notion of common good, focusing on merely individual goods and making impossible the rational justification of ethical solidarity. It is concretized in the rights, virtues, norms, duties, or the remaining realities of that nature. In conclusion, we will claim the necessary link between ethical solidarity and the idea of the common good.
\end{abstract}

\section{KEYWORDS}

Solidarity. Ethics. Common good. Liberalism.

\section{SUMÁRIO}

1. A questão a estudar. 2. O fundamento da solidariedade moral. 3. O desaparecimento de deveres-direitos de solidariedade no liberalismo. 4. Balanço conclusivo. Referências. Dados da publicação.

\footnotetext{
* Publicação original em espanhol: MASSINI-CORREAS, Carlos Ignacio. ¿Existen derechos de solidaridad? La tradición clásica y las propuestas liberales. Prudentia Iuris, n. 86, p. 191-208, 2018. Tradução para a língua portuguesa por Denis Guilherme Rolla (Mestre em História do Direito, PPGD-UFRGS). Revisão da tradução por Alfredo de J. Flores (PPGD-UFRGS). Cabe aqui um agradecimento à equipe editorial da Prudentia Iuris, na pessoa de seu diretor, o Prof. Dr. Nicolás Lafferriere, pela autorização desta tradução.

** Advogado, doutor em Direito e Filosofia, professor universitário (Universidade de Mendoza; Universidade Austral). E-mail: carlos.massini@um.edu.ar
} 


\section{A QUESTÃO A ESTUDAR}

Durante os anos 1930 até os anos 1960, vários autores do então vigente "positivismo lógico" sustentavam a alegação de que a ciência se reduzia a "uma linguagem bem feita". Como ocorre com todos os reducionismos, essa afirmação é lisa e claramente falsa, mas contém - tal como acontece com quase todas as falsidades - uma parte da verdade. Se bem é certo que o conhecimento científico não se reduz a uma mera linguagem bem feita, é indubitável que esse saber inclua a precisão, exatidão e regularidade da linguagem científica características necessárias para se alcançar o rigor e a consistência que são próprios do conhecimento racionalmente verificado.

Isso implica que qualquer tentativa de explicar cientificamente o conteúdo de algum termo - e de sua noção correspondente - supõe uma determinação prévia do significado preciso quando esse termo seja empregado, de modo que se evite a vagueza que leva à polissemia de uma grande quantidade de palavras, em especial as mais usadas no campo da práxis humana e do seu estudo. Essa conveniência de precisar previamente o significado das palavras a serem usadas no discurso acadêmico foi muitas vezes destacada pelos filósofos analíticos $^{2}$ - mas não só por eles - e constitui uma exigência indispensável do pensar corretamente e do explicar compreensível.

No caso que agora nos ocupa, as expressões "solidariedade", "solidário" e seus derivados, como a maioria das expressões pertencentes ao âmbito da práxis humana e que contêm uma carga axiológica indubitável, foram utilizados de maneira anárquica e interessada e, às vezes inclusive, simplesmente de modo descuidado. Assim, por exemplo, falou-se frequentemente de "direitos de solidariedade" referindo-se a pretensões ideais esgrimidas no âmbito internacional, pretensões essas que, na maioria dos casos, nem sequer são propriamente "direitos"3.

Para efeitos de precisar o uso desses termos - "solidário" e "solidariedade" - o melhor é começar, tal como se faz usualmente, por sua etimologia, para passar logo à análise de seus usos na linguagem corrente. A respeito da primeira, afirma Gabriel Amengual que "o termo

1 Acerca do "positivismo lógico", ver: PASSMORE, John. A Hundred Years of Philosophy. London: Penguin, 1968. p. 367-424; AYER, A. J. (Comp.). El positivismo lógico. México: FCE, 1986. p. 9-34.

2 Sobre a concepção analítica da filosofia, ver: ENGEL, Pascal (ed.). Précis de philosophie analytique. Paris: PUF, 2000.; TUGENDHAT, Ernst. Introduzione alla filosofia analitica. Genova: Marietti, 1989.; MASSINICORREAS, Carlos I. Sobre ética y filosofia analitica: Elizabeth Anscombe y la filosofía moral moderna. Mendoza: Centro de Estudios de Filosofía Clásica, 2015.

3 Ver: INCIARTE, Fernando. Derecho natural o derecho racional. Treinta tesis y una propuesta. In: Liberalismo y republicanismo: Ensayos de filosofía política. Pamplona: EUNSA, 2001. p. 171-187; MASSINI-CORREAS, Carlos I. Derecho natural, derechos humanos y derechos de la tercera generación, manuscrito. 
'solidariedade' procede de uma expressão jurídica latina, in solidum (in solidum cavire), nome de uma conhecida figura do direito, que designa a relação jurídica [...] contraída conjuntamente por um grupo e a respeito da qual cada membro do grupo responde na totalidade [...]". Resume esse autor: "É, pois, uma relação de obrigação que faz com que todos os devedores, mesmo individualmente, respondam pela dívida, e isso significa que todos são responsáveis por ela, porque cada um responde pela totalidade da dívida"4. Trata-se, portanto, de um caso extremo de responsabilidade compartilhada por certas obrigações ou dívidas.

Mas é manifesto que essa expressão "in solidum”, por sua vez, deriva da palavra latina solidus ${ }^{5}$, que significa claramente "sólido" (sem espaços vazios, de consistência densa, firme e substantiva $^{6}$, ou dotado de uma unidade consistente), o que designa - no âmbito dos saberes sociais - qualquer ente social dotado de uma unidade que, embora seja do tipo relacional, é especialmente compacta ou consistente ${ }^{7}$. Em outras palavras e passando da etimologia ao uso corrente das palavras, fala-se da "solidez" de um grupo quando sua unidade é particularmente travada e firme. De tudo isso se deriva que, quando se fala de grupos sociais, se os qualifica como "sólidos" por analogia com a "solidez" dos corpos materiais, quando sua união resulta especialmente concentrada, resistente e duradoura. E, por sua vez, "solidariedade" se refere à responsabilidade coletiva que se atribui aos integrantes dos grupos sociais dotados de uma certa "solidez".

No entanto, é claro que a responsabilidade compartilhada das obrigações in solidum tem como fundamento principal a unidade - a "solidez" - que forma aqueles que são os devedores solidários, uma unidade que, no caso de grupos sociais, reveste um caráter eminentemente finalista, de um "telos". Ou seja, uma das noções, a de responsabilidade comum, deriva da outra, a de unidade firme, de modo que a segunda é uma condição necessária da primeira; em outras palavras, sem uma unidade relacional consistente de sujeitos humanos, de fundamento principalmente teleológico, não pode se dar a responsabilidade solidária.

Mas também é necessário salientar que, no caso da solidariedade de responsabilidade, ela pode ser vista pelo menos desde duas perspectivas principais: (i) como fato social,

4 AMENGUAL, Gabriel. Antropología filosófica. Madrid: BAC, 2007. p. 377.

5 Ver: SEGURA MUNGUÍA, Santiago. Diccionario etimológico latino-español. Madrid: Anaya, 1985. p. 680681.

6 Ver: ONIONS, Charles Talbut et al. (ed.). The Oxford Dictionary of English Etymology. Oxford: Clarendon Press, 1994. p. 844.

7 Ver: SOLIDARIO. In: DICCIONARIO de la Real Academia Española. Madrid: Real Academia Española, 2020. Disponível em: <https://dle.rae.es/solidario?m=form>. Acesso em: 15 jul. 2015. 
estudado pela sociologia ou psicologia social; ou (ii) como realidade ética, geradora de valores, deveres e virtudes. Nesse sentido, Gabriel Amengual afirma que "importa distinguir uma perspectiva dupla quando se fala de solidariedade. Por um lado, afirma-se a vinculação fática que une os humanos na realização de sua existência. É o fato antropológico e social de vinculação que apresenta a solidariedade como um fato. Por outro lado e tendo conexão com a perspectiva anterior, é apresentada como um dever, dando-lhe significado não apenas descritivo, mas também normativo: dado que não se pode cogitar da vida sem contar com os demais, devemos nos comprometer com e por eles, pela coletividade, a comunidade, a sociedade - é a solidariedade como dever moral" 8 .

A primeira das perspectivas é a dos sociólogos, e mais ainda dos pensadores de sociologia política, que concebiam a filosofia e a teoria políticas como meramente descritivas e desprovidas de valorações, conforme um conhecido dictum de Max Weber. Entre esses pensadores sociólogos, destacou-se Léon Duguit, que, há quase um século, escreveu que "a solidariedade social [...] deve ser compreendida cientificamente, não é um sentimento, muito menos uma doutrina; nem sequer é um princípio de ação. É um fato de ordem real suscetível de demonstração direta: é o fato da estrutura social mesma"". Estranhamente, a maioria desses pensadores, depois de descrever o fenômeno social da solidariedade humana, passou a defender alegremente o ideal de uma vida social presidida pela solidariedade, em oposição à perspectiva cruamente individualista proposta pelo liberalismo a partir do século XVIII. Esse é o movimento que foi chamado de "solidarismo" e que se difundiu especialmente na França durante a segunda metade do século XIX, adotando várias formas diversas e opostas entre si: socialistas, positivistas, social-cristãs etc. ${ }^{10}$

O principal problema que se coloca às versões positivistas do solidarismo é que sua pretensão de extrair, de meros fatos sociais, ideais e princípios de conduta política carece completamente de um caráter de ilação lógica; sempre que sejam meras declarações descritivas - por mais que se as qualifique de "científicas" - não é possível extrair proposições diretivas da conduta humana sem a mediação de uma ou mais proposições normativas. E, nessas versões, não aparece, pelo menos explicitamente, uma apresentação

8 AMENGUAL, Gabriel. Antropología filosófica. Madrid: BAC, 2007. p. 377.

9 DUGUIT, Léon. Traité de Droit constitutionnel. Tomo I. Paris: E. de Boccard, 1921. p. 278 (ênfase nossa).

10 Sobre o "solidarismo" do séc. XIX, ver: EWALD, François. Solidaridad. In: CANTO-SPERBER, M. Diccionario de ética y de filosofia moral. Tomo II. Ciudad de México: FCE, 2011. p. 1524-1532. Tradução de C. Ávila e outros. 
dessa instância normativa ou deôntica, capaz de outorgar praticidade a um raciocínio de raízes teoréticas. ${ }^{11}$

A segunda das perspectivas a partir das quais a solidariedade pode ser abordada é a prático-moral, que desenvolve seus raciocínios numa chave primeiramente normativa e que pode, desse modo, proporcionar os princípios éticos da conduta humano-social qualificável como "solidária". Nesse sentido, Nicolai Hartmann escreveu, em sua monumental "Ética", que "essa solidariedade, que consiste em responder sem vacilar o indivíduo pelo conjunto, é um autêntico valor de virtude. Pois é um valor de disposição de ânimo da pessoa concreta, por muito que somente saia à luz a magnitude de seu vigor no grande efeito global" ${ }^{12}$. Ou seja, trata-se aqui da solidariedade entendida como um dever moral, uma virtude e um bem humano, segundo a qual a unidade moral das sociedades é um bem/fim a ser alcançado, através do cumprimento de certos deveres e com a ajuda e a direção de uma disposição específica de ânimo, para retomar a expressão proposta por Hartmann.

A partir do que se resumiu até agora, depreende-se que, quando se fala em "solidariedade", pode-se fazer referência tanto a um mero fato social quanto a um bem a ser alcançado na vida coletiva, que fundamenta um dever moral de buscá-lo e gera uma virtude que inclina o homem a realizá-lo habitualmente de um modo excelente. Por razões elementares de especialidade, a partir de agora, somente se tratará da perspectiva ética da solidariedade, fazendo-se referência a certos fatos sociais apenas no marco ético e com o sentido de explicitar e justificar aquelas exigências morais. Por outro lado, deve-se notar que a solidariedade, tanto no nível fático quanto no ético, ocorre em vários níveis da organização social humana, ou seja, nos diferentes grupos sociais que o homem forma para a realização de sua vida: familiares, locais, profissionais, econômicos, políticos etc. Nesta oportunidade, a análise se limitará ao caso da convivência política ou a sociedade completa - que é o que se refere geralmente quando dos tratamentos da problemática da solidariedade, e que, por outra parte, é indubitavelmente o mais importante para a realização humana.

11 Ver: MASSINI-CORREAS, Carlos I. La falacia de la falacia naturalista Mendoza-Argentina: EDIUM, 1996 (passim).

12 HARTMANN, Nicolai. Ética. Madrid: Encuentro, 2011. Trad. J. Palacios. p. 462. 


\section{O FUNDAMENTO DA SOLIDARIEDADE MORAL}

É bem conhecido que a ética, e especialmente a ética social, tem sido objeto de muitas tentativas de explicação e fundamentação, que vão desde o formalismo kantiano ao utilitarismo anglo-saxão, passando por diversos convencionalismos, as éticas materiais dos valores ou as éticas dialógicas ${ }^{13}$. Mas, uma vez que, para analisar, ainda que brevemente, cada uma dessas alternativas, seriam necessárias pelo menos as 852 páginas da já mencionada "Ética" de Nicolai Hartmann, na sequência nos centraremos nas propostas da ética clássica da raiz aristotélica, especialmente em versões contemporâneas propostas por autores como Agustin Fagothey, John Finnis, Alasdair MacIntyre ou Antonio Millán-Puelles.

Uma das notas centrais das éticas de matriz aristotélica é que são doutrinas de caráter teleológico centradas na ideia do bem humano; em torno dessa ideia giram os demais elementos componentes das teorias éticas: normas, virtudes, deveres, valorações etc. Nesse sentido, as normas são proposições racionais práticas que dirigem genericamente a ação humana para o bem; as virtudes éticas consistem em disposições de ânimo operativas que orientam e promovem em concreto a conduta em direção à realização de algumas das dimensões do bem humano; deveres são exigências com necessidade deôntica sobre o bem que deve ser feito na vida moral e assim por diante ${ }^{14}$. Portanto, é inquestionável que, em todos os casos, a justificação racional dos elementos enumerados esteja em sua ordenação finalista (a um "telos") para algumas das determinações do bem humano.

Também nessa concepção clássica, um dos pressupostos fundamentais de qualquer sistema ético consistente é o do caráter social do empreendimento da realização do bem humano; de fato, desde essa perspectiva, não apenas a vida social é necessária como instrumento para a concreção de todos os bens humanos, mas também que a mesma vida social é um elemento integrante da vida boa. Dito de outro modo, a cooperação social não se reduz a um mero meio para a conquista de bens como a suficiência material para a vida, ou conhecimento teórico e prático, ou o trabalho e o lazer, mas a própria vida social - ou sociabilidade - é uma dimensão central do bem humano; assim, a amizade, a vida política ou familiar, a vida universitária e tantas outras dimensões sociais integram eminentemente o bem humano. Voltaremos em breve sobre esse assunto.

13 A modo ilustrativo, ver: GRAHAM, Gordon. Eight Theories of Ethics. London \& New York: Routledge, 2004; MISSNER, Marshall. On Ethics. Belmont-CA: Wadsworth-Thompson Learning, 2002.

14 Ver, neste ponto: FAGOTHEY, Austin. Ética: Teoría y aplicación. México: Interamericana, 1973. Tradução de C. G. Ottenwaelder. 
Além disso, nessas dimensões sociais, o bem que se procura não consiste em um ou mais bens meramente individuais, mesmo que sejam muitos deles, mas especificamente em um bem comum, que pode ser definido, acompanhando aqui Millán-Puelles, como aquele que "é apto para ser participado por todo e cada um dos membros de uma comunidade ou sociedade de pessoas humanas"15. Em outras palavras, o bem de cada um dos membros de uma comunidade é um bem geral que é participado pelos membros da comunidade de referência. Além disso, como escreve Millán, "ser [um bem do todo] não é simplesmente ser maior que a parte, mas ser algo essencialmente distinto. A soma das partes é algo que realmente o todo é, mas não é tudo o que este realmente é, porque não leva em conta que aquelas [partes] se organizam em cada caso de uma certa maneira, que na realidade não é indistinta [...] Ser um todo não é apenas ser maior que cada uma das partes, mas ser outra coisa especificamente diferente..."16.

A rigor, essa realidade especificamente diferente do bem comum consiste em que, no seu caso, é um bem de ordem, ou estrutural, que se radica na disposição ou organização das partes, de modo tal que resulte em um bem maior. Assim, por exemplo, o bem humano do conhecimento teórico e prático tem uma dimensão pessoal: a do conhecimento concreto que cada indivíduo pode adquirir; mas também possui uma dimensão comum: a organização pública do conhecimento (que inclui a educação pública), de tal forma que venha a atender do melhor modo o maior número possível de membros da comunidade política. Isso significa que, quanto a seu conteúdo, o bem comum é parcialmente diferente do bem individual ${ }^{17}$, enquanto consiste em uma organização e disposição de bens humanos a fim de torná-los melhores e mais acessíveis aos particulares; mas, ao mesmo tempo, tem uma semelhança, na medida em que não é um bem humano propriamente dito - nem tampouco comum - se não for participável pelos indivíduos que compõem a comunidade.

Agora, esse bem comum - lembremos que estamos nos referindo especificamente ao bem comum político - é, no pensamento clássico, o fundamento de obrigações políticas e

15 MILLÁN-PUELLES, Antonio. Bien común. Gran Enciclopedia Rialp, Tomo IV. Madrid: Rialp, 1971. p. 225. Sobre as ideias de Millán-Puelles neste ponto, ver: FORMENT, Eudaldo. La filosofía del bien común. Anuario Filosófico, Pamplona, v. XXVII, n. 2, 1994, p. 797-815. Num sentido similar, Tomás de Aquino escrevia que "es manifiesto además que en toda comunidad de creaturas nada es bueno que no lo sea por participación" ( Summa Theologiae, I, q. 103, a. 2c). Acerca deste texto do Aquinate e de outros vinculados, ver: CARDONA, Carlos. $L a$ metafisica del bien común. Madrid: Rialp, 1966.

16 MILLÁN-PUELLES, Antonio. Léxico filosófico. Madrid: Rialp, 1984. p. 377.

17 A este respeito, afirma Tomás de Aquino que "el bien común de la ciudad y el bien singular de una persona no difieren solamente según lo mucho y lo poco, sino según diferencia formal, pues una es la razón de bien común y otra la de bien singular..." (Summa Theologiae, II-II, q. 59, a. 7, ad 2). 
deveres jurídicos ${ }^{18}$. Isso ocorre porque o bem moral, isto é, o que deve ser realizado através da ação humana e se refere à perfeição do homem completo, ao longo de sua vida e em harmonia com os demais homens e com o resto da natureza ${ }^{19}$, é naturalmente exigente, ou demandante, ou ainda necessitante, no sentido de que compele à sua prossecução e realização, coloca uma reivindicação inescusável a nossa conduta. Essa demanda tem a forma de uma necessidade, que não é de caráter físico, nem psicológico, nem lógico, nem muito menos metafísico ou biológico, mas simplesmente moral - "a [necessidade] do dever ser, que nos guia em direção ao que reconhecemos, constitui o uso apropriado de nossa liberdade. [...] A necessidade moral me afeta, o sujeito atuante, mas provém do objeto..." ${ }^{20}$. Objeto que consiste em um bem que integra a vida boa e aparece como um elemento inescusável de sua realização.

No caso das comunidades de vida humana, especialmente a política, esse bem acaba sendo, como explicado acima, um bem comum, suscetível de ser participado pelos integrantes da comunidade. Mas esse bem, na medida em que é realizável por meio da conduta e integra a perfeição do homem enquanto homem, resulta ser um bem moral, que exige ser promovido e realizado por todos aqueles que integram o grupo social; e, por sua vez, deve ser intrinsecamente participável por esses mesmos integrantes, pois, do contrário, não seria um bem propriamente comum. Ou seja, o bem comum o é em duas dimensões: (i) quanto à sua realização por todos os membros do grupo social, e (ii) quanto à sua fruição de modo participativo pelos integrantes desse grupo.

E essas duas dimensões, por sua vez, geram dois tipos de deveres: (i) os deveres de cooperação com a realização do bem comum, que são classicamente chamados de deveres de justiça geral; e (ii) os deveres de distribuição do que é produzido desde a justiça geral, deveres que estão a cargo da autoridade política e que são chamados deveres de justiça distributiva. Mas, por sua vez, esses deveres geram, no âmbito jurídico, os direitos das contrapartes correspondentes, seja das autoridades para contribuir para o bem comum, seja dos particulares para a distribuição desse bem ${ }^{21}$. Um exemplo dos primeiros são os impostos que os membros da comunidade política devem aportar para o tesouro público, a fim de permitir a realização das tarefas exigidas pelo bem comum; e dos segundos, os investimentos

18 Trata-se aqui da denominada doutrina da politicidade do direito, sobre a qual se pode ver: SOAJE RAMOS, Guido. Sobre la politicidad del derecho: el bien común político. In: CASTAÑO, Sergio; SOTO KLOSS, Eduardo (eds.). El derecho natural en la realidad social y jurídica. Santiago de Chile: Universidad Santo Tomás, 2005. p. $15-45$.

19 Ver neste ponto: GARCÍA-HUIDOBRO, Joaquín. El anillo de Giges: Una introducción a la tradición central de la ética. Santiago de Chile: Editorial Andrés Bello, 2005. p. 223-225.

20 FAGOTHEY, Austin. Ética: teoría y aplicación. Ciudad de México: Interamericana, 1973. p. 49.

21 Ver: FORMENT, Eudaldo. La filosofía del bien común. Anuario Filosófico, Pamplona, v. XXVII, n. 2, 1994, p. 801 . 
que o governo deve fazer para a construção e manutenção da infraestrutura que venha a possibilitar a circulação de mercadorias essenciais para a atividade econômica do país.

Mas, em ambos os casos, deve-se reiterar, a razão justificativa destes direitos se radica no caráter de "bem", perfeição humana, que corresponde ao bem comum; e é por isso que é possível falar aqui dos "direitos de solidariedade", uma vez que seu fundamento reside na comunidade desse bem, que é responsabilidade de todos e existe em benefício de todos. Tratase, então, de um caso especial de direitos solidários, os de "solidariedade política", que são incumbência de todos e favorecem a todos, isso porque todos formam uma única unidade moral ordenada para a realização de um bem comunitário ${ }^{22}$.

Agora, nesta questão de direitos, também deve ser destacado aqui que, como Gewirth colocou corretamente ${ }^{23}$, para que se possa falar apropriadamente de um direito-faculdade, seria necessária a presença de pelo menos quatro elementos: (i) um sujeito titular do direitofaculdade (A); (ii) o objeto ou matéria sobre a que versa o direito (X); (iii) a contraparte do sujeito titular, ou sujeito devedor (B); e, finalmente, (iv) a base justificativa do direito (Y). A partir desta análise, este autor propõe uma fórmula geral que expressa descritivamente o que é "um direito": "A tem direito a X ante B, em virtude de $Y$ ”. Aplicando-se este esquema ao caso dos direitos de solidariedade distributivos, aparece claramente que são seus sujeitos titulares todos os integrantes do grupo social em que esses direitos têm validade; seu objeto próprio é o conteúdo - material, de coordenação e espiritual - do bem comum político; o sujeito devedor é a comunidade completa, representada por suas autoridades legítimas; e sua base justificativa se radica no caráter comum - intrinsecamente participável - do bem ao que se ordena a existência da sociedade completa ou política. Desse modo, ficam suficientemente explicados - ainda que esquematicamente - a estrutura, o objeto e o sentido dos denominados "direitos de solidariedade".

Segue-se disso que o caráter comum, ou seja, intrinsecamente participável, do bem próprio da comunidade política supõe que todos têm o dever de contribuir para a sua formação e que todos também têm o direito formal de participar dos benefícios que dele resultam. Nisso se radicam os direitos da solidariedade: em que todos devem contribuir para a resolução de problemas comuns e, ao mesmo tempo, a totalidade dos membros do grupo

22 Ver: CHALMETA, Gabriel. Ética social: Familia, profesión y ciudadanía. Pamplona: EUNSA, 2007. p. 198199.

23 GEWIRTH, Alan. Are there any Absolute Rights? In: WALDRON, Jeremy (ed.). Theories of Rights. Oxford: Oxford University Press, 1984. p. 95. Para uma maior explicitação desta doutrina, ver: MASSINI-CORREAS, Carlos I. Filosofia del Derecho I: El derecho, los derechos humanos y el derecho natural. Buenos Aires: LexisNexis/Abeledo-Perrot, 2005. p. 90-96. 
político social pode exigir uma participação adequada em seus resultados. Assim, por exemplo, todos os membros da sociedade política devem colaborar, v.g. através do imposto, para com o funcionamento de um sistema público de saúde, sistema ao qual a integralidade dos sujeitos dessa comunidade tem direito a um acesso adequado, mesmo quando não dispõem de meios econômicos - e especialmente nesses casos - para quitar suas prestações. E tudo isso porque o bem da saúde tem uma dimensão comum, que racionalmente fundamenta e justifica esse jogo de direitos e deveres.

Mas, além disso, convém precisar neste ponto que, mais além das funções propriamente políticas na promoção, gestão e distribuição do bem comum - funções principalmente de coordenação, controle e direção arquitetônica - as pessoas individuais e os grupos sociais infrapolíticos têm uma tarefa imprescindível para cumprir, tanto na contribuição como na distribuição desse bem. Com efeito, conforme o princípio conhecido como "de subsidiariedade", essas pessoas e esses grupos estão facultados - e em certos casos obrigados - à prestação dos serviços que integram o bem comum, na medida de suas capacidades e possibilidades. E como contrapartida dessa faculdade - que tem uma presença especial no recentemente mencionado âmbito da saúde pública - a autoridade política não deve interferir ou recortar essas faculdades, mas apenas supervisionar e colaborar com seu exercício. Este tema da subsidiariedade é demasiado extenso para ser tratado adequadamente aqui, mas vale a pena lembrar e reafirmar ${ }^{24}$.

\section{O DESAPARECIMENTO DE DEVERES-DIREITOS DE SOLIDARIEDADE NO}

\section{LIBERALISMO}

Dito isso, tal ideia de solidariedade política, fundada na finalidade daquele bem comum que é próprio da comunidade política, entrou em crise desde o último quarto do século XX, devido ao que Alasdair MacIntyre chamou de "privatização do bem nas sociedades liberais", e que, ele conceitua dizendo que "o divórcio entre as regras que definem a ação correta, por um lado, e as concepções do bem humano, por outro, é um dos aspectos pelos quais certas sociedades são chamadas liberais [...]; uma vez que os compromissos relativos à elaboração, defesa e vivência das concepções particulares do bem humano são, desde este ponto de vista liberal, atribuídos e restritos à esfera da vida privada dos indivíduos,

24 Neste ponto, ver: ALVARADO, Claudio; VILLARROEL, Eduardo Galaz. Subsidiaridad y vida pública: una mirada a los orígenes. In: ORTÚZAR, Pablo (ed.). Subsidiariedad: Más allá del estado y del mercado. Santiago de Chile: Instituto de Estudios de la Sociedad, 2015. p. 33-51. Ademais: FINNIS, John. Natural Law and Natural Rights. $2^{\mathrm{a}}$ ed. Oxford: Oxford University Press, 2011. p. 146 e passim. 
aquilo que é concernente à obediência ante o que se considera como regras morais exigidas por qualquer pessoa moral, pode ser legitimamente buscado em domínio público" 25 . Terreno onde ocorrem acordos, ações dialógicas e procedimentos que são os que, numa linha liberal, aparecem como os únicos capazes de justificar a moralidade pública.

O expoente mais completo dessa abordagem liberal ao problema da solidariedade política está no livro de Robert Nozick "Anarquia, Estado e utopia”, no qual o antigo professor de Harvard sustenta a ideia de um Estado ultramínimo, que seria o único capaz de obter justificação moral, já que qualquer outra forma mais intensa e complexa de comunidade política seria intrinsecamente imoral. Sustenta este autor: "Posto que começo com uma vigorosa afirmação dos direitos individuais, trato seriamente a afirmação anarquista de que o Estado, no processo de manter o monopólio do uso da força e de proteger a todos dentro de um território, deve necessariamente violar os direitos dos indivíduos e, portanto, é intrinsecamente imoral [...]”. E conclui: “o Estado mínimo é o único justificável”26.

Algo similar - embora não tão extremo - ocorre com o pensamento de John Rawls. Segundo esse último autor, qualquer bem humano deve necessariamente ser o de um indivíduo em particular, já que os bens nada mais são que o objeto ocasional de um desejo e a correspondente preferência individual. Desse modo, “o bem só pode ser privado e exclusivo de cada indivíduo e, portanto, a proposta de um bem qualquer para uma comunidade de seres humanos não pode significar outra coisa que a imposição de um bem próprio de um sujeito ao restante de sujeitos autônomos, uma imposição que só pode ser injusta"27. Esse é um dos pressupostos dogmáticos da ideologia liberal, para a qual a inexistência de bens comuns - e especialmente do bem comum político - tem como consequência que nunca um bem privado (o único que existe) de um sujeito individual possa valer para outro ou outros sujeitos individuais; isso porque será apenas um bem próprio de outra pessoa e sua tentativa de fazer valer para as demais pessoas parecerá uma imposição injustificada, pelo menos no contexto de uma mera coexistência de autonomias ${ }^{28}$.

\footnotetext{
25 MACINTYRE, Alasdair. The Privatization of Good. An Inaugural Lecture. The Review of Politics, Notre Dame, 1990, n. 52/3, p. 346.

26 NOZICK, Robert. Anarquía, estado y utopía. México: FCE, 1988. p. 8-9.

27 MASSINI-CORREAS, Carlos I. Privatización y comunidad del bien humano. El liberalismo deontológico y la respuesta realista. Anuario Filosófico, Pamplona, v. XXVII, n. 2, 1994, p. 818.

28 Sobre o termo "autonomia" e seus significados, ver: MASSINI-CORREAS, Carlos I. Autonomía y bienes humanos. ¿Existe un principio ético de autonomía?. In: Teoría del derecho y de los derechos humanos. Lima: ARA Editores, 2011. p. 67-95. Para o estudo da saga da noção ética de autonomia, ver: SCHNEEWIND, Jerome B. La invención de la autonomía: Una historia de la filosofía moral moderna. Ciudad de México: FCE, 2009. Tradução de J. H. Ruiz Rivas.
} 
E essa conclusão liberal é estritamente coerente; com efeito, caso se negue a existência de bens comuns objetivos ${ }^{29}$, aqueles em que todos podem participar e se beneficiar, então resultaria impossível sustentar a possibilidade de que um bem escolhido e preferido por um sujeito $\mathrm{X}$ possa valer igualmente para um sujeito $\mathrm{Y}$, individualmente diverso do anterior e com outro sistema, diferente, de preferências. Poderia ocorrer, por mera casualidade, a circunstância de que acidentalmente duas preferências coincidam, mas se tratará sempre de uma situação meramente contingente e de muito improvável realização. Em princípio, as eleições meramente autônomas de um indivíduo, as únicas que neste esquema "geram" bens, não têm valor moral algum para outro indivíduo diferente.

É notório que, desde essa perspectiva liberal, a solidariedade política pode aparecer tanto como um fato ou como uma escolha ocasional e individual de algum sujeito, mas não alcançará a justificação racional necessária para transformá-la em um dever e seu direito correlato. E é por isso que a grande maioria dos autores liberais não faz referência a deveres estritos de solidariedade. De fato, em seu recente volume "Justiça para ouriços", Ronald Dworkin dedica 592 páginas para desenvolver a última versão de sua teoria da justiça, mas em nenhuma parte, nem de passagem, fala de deveres jurídicos de solidariedade ${ }^{30}$.

Mas também, mesmo nos casos em que alguns autores liberais fazem referência a deveres e direitos sociais, percebe-se claramente que, nesta situação, são realidades de caráter meramente instrumental, ou seja, úteis para a posse e o gozo de direitos individuais, que são os únicos que têm valor em sua sistemática. Nesse sentido, Gabriel Chalmeta escreve que "segundo o juízo da filosofia mais influente hoje na opinião pública, de índole utilitarista e no fundo - individualista (não autenticamente altruísta), a interdependência ética entre os homens, a necessidade que alguns têm dos outros para bem poder viver, refere-se unicamente à ordem dos meios. Seria, sim, absolutamente necessário estabelecer uma certa colaboração entre indivíduos [...]; mas o objetivo que todas essas relações de colaboração devem buscar é que cada indivíduo em particular consiga satisfazer uma série de necessidades e desejos que são estritamente seus [individuais]"31.

\footnotetext{
29 Michael Sandel, referindo-se às ideias de John Rawls, afirma que, para ele, "el hombre es por naturaleza un ente que elige sus bienes, más que un ente que, como lo concebían los antiguos, descubre sus bienes" (SANDEL, Michael. Liberalism and the Limits of Justice. Cambridge: Cambridge University Press, 1992. p. 22).

30 Ver: DWORKIN, Ronald. Justicia para erizos. México: FCE, 2014. Trad. H. Pons \& G. Maurino.; de sua parte, James Griffin sustenta em seu livro "On Human Rights" que as exigências da justiça distributiva não se vinculam aos direitos humanos; isto é, não existem direitos de distribuição (GRIFFIN, James. On Human Rights. Oxford: Oxford University Press, 2008. p. 64).

31 CHALMETA, Gabriel. Ética social: Familia, profesión y ciudadanía. Pamplona: EUNSA, 2007. p. 76.
} 
Em outras palavras, desde uma perspectiva estritamente liberal, as relações de justiça, a vida boa em comum, a perfeição humana social, amizade e concórdia política $^{32}$ não consistiriam em bens humanos intrínsecos, valiosos em si mesmos, mas meramente instrumentos que servem apenas para bens individuais. Isso significa necessariamente que, na medida em que as estruturas sociais não satisfazem plenamente os interesses privados dos indivíduos, deixarão de ter qualquer valor de caráter positivo e carecerão da força deôntica suficiente para justificar deveres e direitos.

Agora, é sabido que essa não é a perspectiva própria do pensamento clássico, mesmo desde as suas origens, quando Aristóteles escreveu que os homens "mesmo quando não tenham necessidade da ajuda recíproca, ainda querem viver juntos [...]; [porque] também se reúnem simplesmente para viver e constituem a comunidade política, pois quiçá no mero viver [juntos] haja certa dose de bondade..." ${ }^{33}$. E ainda mais preciso, neste ponto, é um texto de Tomás de Aquino, quando sustenta que "em virtude de sua natureza social ou política, [os homens] tendem a viver juntos e não isolados, mesmo na suposição de que alguém não tivesse a necessidade do outro para obter essas vantagens sociais" 34 . De sua parte, John Finnis, apesar de reconhecer o caráter instrumental de certas dimensões do bem comum, sustenta que aquelas comunidades "que têm um bem comum que é mais instrumental que básico, através da associação e cooperação para um bem instrumental (tal como uma empresa de negócios), revestem um caráter mais que instrumental na medida em que concretizam o bem básico da amizade [e da socialidade] em uma ou outra de suas formas centrais ou não-centrais" ${ }^{35}$.

Em resumo, é necessário destacar que, desde a perspectiva liberal, o bem que as coletividades humanas perseguem, especialmente a política, reveste um caráter simplesmente instrumental quanto aos interesses e aos bens de seus membros e, por si só, carece de todo caráter intrínseco. Conclui-se, portanto, que nessa perspectiva não há lugar para uma autêntica solidariedade, ou seja, aquela que teria a sua razão de ser no bem de todos, buscando, procurando o bem dos demais do mesmo modo que se busca e se procura a participação pessoal no bem da coletividade. Evidentemente, isso não exclui que possa haver um sentimento de solidariedade entre os membros da comunidade política, radicado no nível meramente afetivo, mas sempre se tratará de um mero fato psicológico-social, sem relevância

32 Neste ponto, ver: LAMAS, Félix. La concordia política. Buenos Aires: Abeledo-Perrot, 1975.

33 ARISTÓTELES, Politica, III, 6, 1278 b.

34 TOMÁS DE AQUINO, In Politicorum, V, 387.

35 FINNIS, John. Limited Government. In:

Oxford: Oxford University Press, 2011. p. 89. 
no âmbito propriamente da eticidade, que se refere às razões - que são sempre bens decisivas para agir ${ }^{36}$.

\section{BALANÇO CONCLUSIVO}

De tudo o que foi exposto até agora, é possível inferir as seguintes conclusões acerca da problemática da solidariedade ética e sua relação com os direitos:

a) Em primeiro lugar, deve-se dizer algo sobre o valor epistêmico quanto a esclarecer o sentido preciso das palavras que se usam num trabalho especializado, já que o contrário, isto é, a vagueza no uso dos termos, só pode conduzir para a confusão e a perda de todo valor enquanto contribuição ao saber racionalmente justificado.

b) Por outro lado, resulta claro que uma noção precisa de solidariedade supõe também um conceito preciso de sociedade, ou grupo social, e de seu bem próprio; toda vez que estivesse fora desse contexto, a expressão solidariedade só pode ser pensada enquanto um sentimento somente individual, identificável em um nível meramente fático ou psicológicosocial, mas alheio ao plano prático-normativo; e, neste último plano, a solidariedade se constitui no marco de comunidades de vida ordenadas para a realização de um fim/bem de caráter ético.

c) Esse bem que dá sentido e explica o fenômeno comunitário e solidário deve ser necessariamente um bem comum, isto é, uma perfeição humana participável por todos os integrantes do grupo social; e essa participação deve ser ativa e receptiva: ativa, na medida em que todos devem contribuir para sua constituição; e receptiva, na medida em que a mesma totalidade de integrantes deve poder participar de seus resultados de perfeição; e isso é possível porque, abstração feita dos bens particulares que são seu conteúdo material, sua formalidade própria é a de ser um bem de ordem ou estrutural, pelo qual a disposição de suas partes aumenta e multiplica a sua bondade, e o constitui em um bem distinto e superior aos seus componentes singulares.

d) E é precisamente esse caráter comum do bem social, especialmente do bem político, que justifica racionalmente os deveres de solidariedade que todos os membros têm uns com os outros, bem como os direitos correspondentes de que gozam aqueles que participam desse bem; direitos que, como tudo que é jurídico, têm propriamente o seu âmbito na comunidade política, como também a única possibilidade real de sua vigência efetiva.

36 Ver: FINNIS, John. Introduction. In: Collected Essays - I - Reason in Action. Oxford: Oxford University Press, 2011. p. 01-15. 
e) As doutrinas liberais geralmente não podem justificar racionalmente os deveres e direitos da solidariedade, isso em razão de sua recusa em reconhecer a existência de bens intrinsecamente comuns; sua visão do bem social, como meramente instrumental a serviço dos interesses e preferências individuais, anula a fonte da razoabilidade dos direitos sociais de solidariedade, deixando os sentimentos de solidariedade reduzidos a simples fatos psicológicos individuais.

f) Tudo o que se colocou acima não suprime a possibilidade - antes, vai supor - a existência de uma solidariedade baseada num nível de realidade e de consideração superior: o religioso (especialmente cristão), onde a solidariedade se dá entre todos os seres humanos (e também com o resto da natureza) e se fundamenta na comunidade de todos estes na Criação, ordenada toda ela à perfeição absoluta do Bem comum transcendente, aquele ao qual - nos termos vistos em Tomás de Aquino - todos os homens chamam de Deus, e de onde todos os outros bens participam em sua perfeição ${ }^{37}$. Isso significa que, além da solidariedade que tem o seu lugar no nível humano-racional-imanente - que reveste uma realidade positiva, mas participada e imperfeita -, existe uma solidariedade perfeita ou completa, baseada em um nível de existência e consideração transcendente, e que só pode ser alcançado cruzando os limites do meramente mundano e do aquém-morte.

\section{REFERÊNCIAS}

ALVARADO, Claudio; VILLARROEL, Eduardo Galaz. Subsidiaridad y vida pública: una mirada a los orígenes. In: ORTÚZAR, Pablo (ed.). Subsidiariedad: Más allá del estado y del mercado. Santiago de Chile: Instituto de Estudios de la Sociedad, 2015.

AMENGUAL, Gabriel. Antropología filosófica. Madrid: BAC, 2007.

AYER, A. J. (comp.). El positivismo lógico. Ciudad de México: FCE, 1986.

CARDONA, Carlos. La metafisica del bien común. Madrid: Rialp, 1966.

CARDONA, Carlos. Metafisica del bien y del mal. Pamplona: EUNSA, 1987.

CHALMETA, Gabriel. Ética social: Familia, profesión y ciudadanía. Pamplona: EUNSA, 2007.

DWORKIN, Ronald. Justicia para erizos. Ciudad de México: FCE, 2012. Trad. H. Pons \& G. Maurino.

37 Neste ponto, ver: CARDONA, Carlos. La metafísica del bien común. Madrid: Rialp, 1966. p. 53 et seq.; do mesmo autor: CARDONA, Carlos. Metafísica del bien y del mal. Pamplona: EUNSA, 1987. p. 45-66. 
DUGUIT, Léon. Traité de Droit constitutionnel. Tomo I. Paris: E. de Boccard, 1921.

ENGEL, Pascal. Précis de philosophie analytique. Paris: PUF, 2000.

EWALD, François. Solidaridad. In: Diccionario de ética y de filosofía moral. Tomo II. Ed. M. Canto-Sperber. Ciudad de México: FCE, 2011.

FAGOTHEY, Austin. Ética: teoría y aplicación. Ciudad de México: Interamericana, 1973. Tradução de C. G. Ottenwaelder.

FINNIS, John. Introduction. In: . Collected Essays - I - Reason in Action. Oxford: Oxford University Press, 2011.

FINNIS, John. Limited Government. In: . Collected Essays - III - Human Rights \& Common Good. Oxford: Oxford University Press, 2011.

FINNIS, John. Natural Law and Natural Rights. 2a ed. Oxford: Oxford University Press, 2011.

FORMENT, Eudaldo. La filosofía del bien común. Anuario Filosófico, Pamplona, v. XXVII, n. 2, 1994, p. 797-815.

GARCÍA-HUIDOBRO, Joaquín. El anillo de Giges: Una introducción a la tradición central de la ética. Santiago de Chile: Editorial Andrés Bello, 2005.

GEWIRTH, Alan. Are there any Absolute Rights? In: WALDRON, Jeremy (ed.). Theories of Rights. Oxford: Oxford University Press, 1984.

GRAHAM, Gordon. Eight Theories of Ethics. London \& New York: Routledge, 2004.

GRIFFIN, James. On Human Rights. Oxford: Oxford University Press, 2008.

HARTMANN, Nicolai. Ética. Madrid: Encuentro, 2011. Tradução de J. Palacios.

INCIARTE, Fernando. Liberalismo y republicanismo: Ensayos de filosofía política. Pamplona: EUNSA, 2001.

LAMAS, Félix. La concordia política. Buenos Aires: Abeledo-Perrot, 1975.

MACINTYRE, Alasdair. The Privatization of Good: an Inaugural Lecture. The Review of Politics, Notre Dame, 1990, n. 52/3.

MASSINI-CORREAS, Carlos I. Autonomía y bienes humanos. ¿Existe un principio ético de autonomía? In: Teoría del Derecho y de los Derechos Humanos. Lima: ARA Editores, 2011.

MASSINI-CORREAS, Carlos I. Derecho natural, derechos humanos y derechos de la tercera generación, manuscrito. 
MASSINI-CORREAS, Carlos I. Filosofia del Derecho: I - El derecho, los derechos humanos y el derecho natural. Buenos Aires: Lexis-Nexis/Abeledo Perrot, 2005.

MASSINI-CORREAS, Carlos I. La falacia de la 'falacia naturalista'. Mendoza-Argentina: EDIUM, 1996.

MASSINI-CORREAS, Carlos I. Privatización y comunidad del bien humano. El liberalismo deontológico y la respuesta realista. Anuario Filosófico, Pamplona, v. XXVII, n. 2, 1994.

MILLÁN-PUELLES, Antonio. Bien Común. In: Gran Enciclopedia Rialp. Tomo IV. Madrid: Rialp, 1971.

MILLÁN-PUELLES, Antonio. Léxico Filosófico. Madrid: Rialp, 1984.

MISSNER, Marshall. On Ethics. Belmont-CA: Wadsworth-Thomson Learning, 2002.

NOZIK, Robert. Anarquía, estado y utopía. Ciudad de México: FCE, 1988. Tradução de R. Tamayo.

ONIONS, Charles Talbut et al. (ed.). The Oxford Dictionary of English Etymology. Oxford: Clarendon Press, 1994.

PASSMORE, John. A Hundred Years of Philosophy. London: Penguin, 1968.

SANDEL, Michael. Liberalism and the Limits of Justice. Cambridge: Cambridge University Press, 1992.

SCHNEEWIND, Jerome B. La invención de la autonomía: una historia de la filosofía moral moderna. Ciudad de México: FCE, 2009. Tradução de J. H. Ruiz Rivas.

SEGURA MUNGUÍA, Santiago. Diccionario etimológico latino-español. Madrid: Anaya, 1985.

SOAJE RAMOS, Guido. Sobre la politicidad del derecho: el bien común político. In: CASTAÑO, Sergio; SOTO KLOSS, Eduardo (eds.). El derecho natural en la realidad social y jurídica. Santiago de Chile: Universidad Santo Tomás, 2005.

SOLIDARIO. In: DICCIONARIO de la Real Academia Española. Madrid: Real Academia Española, 2020. Disponível em: $<$ https://dle.rae.es/solidario?m=form $>$. Acesso em: 15 jul. 2015.

TUGENDHAT, Ernst. Introduzione alla filosofia analitica. Genova: Marietti, 1989. 


\section{DADOS DA PUBLICAÇÃO}

Categoria: artigo de autor convidado.

Recebido em: 01/02/2020.

Aceito em: 20/04/2020. 